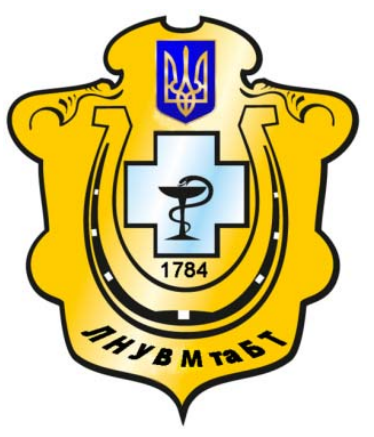

Науковий вісник Львівського національного університету ветеринарної медицини та біотехнологій імені С.3. Гжицького

Scientific Messenger of Lviv National University of Veterinary Medicine and Biotechnologies named after S.Z. Gzhytskyj

doi:10.15421/nvlvet7024

ISSN 2413-5550 print

ISSN 2518-1327 online

$\underline{\text { http://nvlvet.com.ua/ }}$

УДК 619:616.15:616.155.392

\title{
Зміни в крові щурів після імунізації препаратом «Лейкозав» проти лейкозу великої рогатої худоби
}

\author{
А.І. Завірюха ${ }^{1}$, О.І. Віщур ${ }^{2}$, Г.А. Завірюха ${ }^{1}$ \\ dnu.cub@ukr.net \\ ${ }^{1}$ ДНУ «Державний иентр інноваційних біотехнологій», \\ вул. Донецька, 30, м. Київ, 03151, Україна; \\ ${ }^{2}$ Інститут біологї̈ тварин НААН, \\ вул. Василя Стуса, 38, м. Львів, 79000, Україна
}

В статті представлені результати гематологічних досліджень крові щурів за дї препарату «Лейкозав» проти лейкозу великої рогатої худоби.Дослідним тваринам препарат «Лейкозав» вводився двічі з інтервалом у 14 діб по 0,5 см

До введення і після введення досліджено гематологічні показники: число лейкоцитів, еритрочитів і тромбоцитів та їх індекси, вміст гемоглобіну.

За результатами досліджень встановлено, що кількість еритроцитів, вміст гемоглобіну та величина гематокриту зменшуються в межах статистичних похибок і не мають негативного впливу на здоров'я лабораторних тварин.

Введення препарату «Лейкозав» щурам не спричиняло вірогідних змін щчодо показників тромбочитарних індексів у крові тварин на сьому добу після щеплення.

Встановлено зменшення кількості сегментоядернихнейтрофілів $і$ зростання кількості лімфоцитів в одиниці об'єму крові (1 мкл) на 14 та 30 добу після щеплення $(p<0,05-0,01)$ та збільшення кількості моночитів в 1,6 рази через 30 діб після імунізації $(p<0,05)$ у порівнянні з довакиинальним періодом.

Під впливом препарату «Лейкозав» через два тижні після імунізації в крові тварин збільщується кількість базофілів (в 2 - 2,5 рази). У порівнянні з контрольною групою тварин еозинофіли крові піддослідної групи щурів знаходяться у межах показників фізіологічної норми.

Ключові слова: лейкоз великої рогатої худоби, інфекційне захворювання,профілактика, препарат, випробування, гематологічні показники.

\section{Изменения в крови крыс после иммунизации препаратом «Лейкозав» против лейкоза крупного рогатого скота}

\author{
А.И. Завирюха ${ }^{1}$ О.И. Вищур ${ }^{2}$, А.А. Завирюха ${ }^{1}$ \\ dnu.cub@ukr.net \\ ${ }^{I}$ ГНУ «Государственный иентр инновационных биотехнологий, \\ ул. Донеикая, 30, г. Киев, 03151, Украина; \\ ${ }^{2}$ Институт биологии животных НААН, \\ ул. Василия Стуса, 38, г. Львов, 79000, Украина
}

В статье представлены результаты гематологических исследований крови крыс при действии препарата «Лейкозав» против лейкоза крупного рогатого скота. Опьтнымм животным препарат «Лейкозав» вводился дважды с интервалом в 14 дней по 0,5 $\mathrm{cm}^{3}$.

До введения и после введения исследованы гематологические показатели: число лейкоцитов, эритроцитов и тромбоцитов и их индексы, содержание гемоглобина.

\section{Citation:}

Zaviriukha, A.I., Vischu, O.I., Zaviriukha, H.A. (2016). Changes in blood of rats after immunization preparation «Leykozav» against leukemia cattle. Scientific Messenger LNUVMBT named after S.Z. Gzhytskyj, 18, 3(70), 103-107. 
По результатам исследований установлено, что количество эритроцитов, содержание гемоглобина и величина гематокрита уменшаються в пределах статистических погрешностей и не оказывают негативного влияния на здоровье лабораторних животных.

Введение препарата «Лейкозав» крысам не вызывало достоверных изменений по показателям тромбоцитарных индексов в крови животных на седымые сутки после прививки.

Установлено уменьшение количества сегментоядерных нейтрофилов и рост количества лимфочитов в одинице объема крови (1 мкл) на 14 и 30 сутки после прививки (p < 0,05-0,01) и увеличение количества моночитов в 1,6 раза через 30 дней после иммунизации ( $p<0,05)$ по сравнению с довакцинальным периодом.

Под влиянием препарата «Лейкозав» через две недели после иммунизации в крови животных увеличивается количество базофилов (в 2 - 2,5 раза). По сравнению с контрольной груп пой животньх эозинофиль крови подопьтной группь крыс находятся в пределах показателей физиологической нормы.

Ключевые слова: лейкоз крупного рогатого скота, инфекционноезаболевание, профилактика, препарат, испьтания, гематологические показатели.

\title{
Changes in blood of rats after immunization preparation «Leykozav» against leukemia cattle
}

\author{
A.I. Zaviriukha ${ }^{1}$, O.I. Vischu ${ }^{2}$, H.A. Zaviriukha ${ }^{1}$ \\ dnu.cub@ukr.net \\ ${ }^{1}$ State Center of Innovation Biotechnologies, \\ Donetska Str., 30, Kyiv, 03151, Ukraine; \\ ${ }^{2}$ Institute of animal biology NAAS, \\ Vasyl Stus Str., 38, Lviv, 79000, Ukraine
}

The article presents the results of research of hematological blood of rats under the influence of the drug «Leykozav» against bovine leukemia. Experienced animal drug «Leykozav» introduce twice at an interval of 14 days at $0.5 \mathrm{~cm}^{3}$.

Before the introduction and after the introduction of studied hematologic parameters: the number of white blood cells, red blood cells and platelets and their indices, the hemoglobin content.

According to the research found that the number of red blood cells, hemoglobin and hematocrit values are reduced to within statistical error, and no adverse effects on the health of laboratory animals.

The introduction of the drug «Leykozav» rats did not cause any significant changes in terms of platelet indices in the blood of animals on the seventh day after the inoculation.

The decrease number of segmented neutrophils and increase in the number of lymphocytes in the blood unit volume (1 at 14 and 30 days after inoculation $(r<0.05-0.01)$ increase the number of monocytes and 1,6 times at 30 days after immunization $(r<0,05)$ compared to before vaccination period.

Influenced «Leykozav» preparation two weeks after immunization animals increases the amount of blood basophils $(2-2,5 \mathrm{mkl})$. Compared with the control group of animals of the experimental group of blood eosinophils of rats indices are within physiological norms.

Key words: leukemia cattle, infectious disease prevention, testingpreparation, hematology.

\section{Вступ}

Лейкоз великої рогатої худоби (ВРХ) -хронічна інфекційна хвороба, що характеризується злоякісним розростом кровотворної тканини, порушенням дозрівання кровотворних клітин, інфільтрацією органів цими клітинами і утворенням пухлин (Sjurin et al., 2001). Лейкоз великої рогатої худоби - хронічне інфекційне захворювання, яке значно поширене у країнах світу. Епізоотична ситуація щодо лейкозу ВРХ вже більше десяти років залишається напруженою. Незважаючи на зниження загальної кількості хворих тварин в усьому світі інфекційна хвороба реєструється у країнах Європи - Польщі, Молдові, Боснії, Хорватії, Сербії, Греції та в Росії, Білорусії Казахстані, Узбекистані Таджикистані та інших країнах (Gorbatenko and Shapovalova, 2013; Gorbatenko et al., 2014).

Епізоотична ситуація щодо лейкозу ВРХ в Україні свідчить про зниження кількості уражених вірусом лейкозу тварин та кількості неблагополучних пунктів (Busol, 2003; Gorzhejev, 2013; Epizootychna sytuacija,
2015). В останні роки в Україні завдяки зусиллям ветеринарної служби оздоровлений ряд регіонів від цього захворювання. Проте, лишається ще багато областей, де лейкоз широко розповсюджений, а тому $\epsilon$ актуальною ветеринарною проблемою.

У багатьох країнах зарубіжжя та на Україні проводяться пошуки імуногенних препаратів проти онкогенного вірусу лейкозу (Nagajeva and Aranchij, 2003; Krushel'nyc'kyj and Markiv, 2004). Останнім часом 3'явились наукові праці про розробку інактивованих вакцин, які вселяють надію про створення в майбутньому ефективних засобів боротьби 3 цією інфекційною хворобою (Zavirjuha et al., 2003; Tons'ka, 2013; Zavirjuha, 2014).

Незважаючи на досягнуті позитивні результати у боротьбі з лейкозом ВРХ в Україні проблема оздоровлення худоби від захворювання лейкозом залишається актуальною. Стійке благополуччя молочних стад можна вирішити застосуванням профілактичних щеплень поголів'я інактивованою імуногенною вакциною. Для ефективної боротьби і профілактики захво- 
рювання необхідно впровадження нових протилейкозних засобів.

Мета $i$ завдання дослідження. Дослідити вплив препарату «Лейкозав» проти лейкозу великої рогатої худоби на гематологічні показники крові лабораторних тварин (щурів). Дослідити гематологічні показники: число лейкоцитів, еритроцитів і тромбоцитів та їх індекси, вміст гемоглобіну.

\section{Матеріал і методи досліджень}

Для проведення досліджень у віварії Інституту біології тварин НААН були відібрані статево зрілі щурі (n = 50 гол.), аналоги за живою масою $(250-300$ г) та віком. Всі тварини у підготовчий період, який тривав 20 діб, отримували стандартний повноцінний раціон 3 вільним доступом до води. Протягом досліду спостерігали за поведінкою щурів, їх руховою активністю, споживанням корму та води, станом волосяного та шкірного покриву, дихальної і травної систем, звертали увагу на інші індивідуальні особливості.

Після завершення підготовчого періоду відібрано 10 тварин (контроль), яким внутрішньом'язево вводили фізрозчин, після чого їх під легким хлороформним наркозом декапітовано і відібрано зразки крові для вивчення імунологічних та біохімічних досліджень. Іншим 40 тваринам, відповідно до інструкції, внутрішньом'язево, після завершення підготовчого періоду (дослід; 0 доба) та через 14 діб вводили препарат «Лейкозав» у дозі $0,5 \mathrm{~cm}^{3}$.

Після декапітації щурів, відбирали кров у пробіркиз $\mathrm{K}_{2}$ ЕДТА. Використовували для отримання плазми і формених елементів крові, для отримання сироватки ставили пробірку зі зразком крові в термостат на 60 хв при $37^{\circ} \mathrm{C}$, після чого центрифугували 15 хв при 2000 тис об/хв і відбирали сироватку в іншу пробірку. Досліджували наступні гематологічні показники:число лейкоцитів, еритроцитів і тромбоцитів та їх індекси, вміст гемоглобіну.

Всі маніпуляції з тваринами проводили згідно 3 Європейською конвенцією про захист хребетних тварин, що використовуються для дослідних та інших наукових цілей та Закону України«Про захист тварин від жорстокого поводження».

Статистичну обробку одержаних результатів досліджень проводили з використанням програми «Excell 2011» для Windows із обчисленням середніх значень (M), середньоквадратичних відхилень (m) і порівняльних середніх значень із використанням параметричного $\mathrm{t}-$ Стьюдента, з урахуванням порогу вірогідності від $\mathrm{p}<0,05$ до $\mathrm{p}<0,001$.

\section{Результати та їх обговорення}

Результати гематологічних досліджень крові щурів показали, що через 7 діб після введення препарату кількість лейкоцитів збільшується в 1,2 рази. На 14 і 30 добу збільшується або зменшуються показники підрахунку в межах статистичних похибок. Кількість еритроцитів, вміст гемоглобіну та величина гематокриту зменшуються в межах статистичних похибок і не мають негативного впливу на здоров'я тварин (табл. 1).

Після імунізації лабораторних щурів препаратом «Лейкозав» через 7 діб в їх крові збільшується кількість лейкоцитів, майже на 20\% (19,7\%) що суттєво відрізняється від показників, які були виявлені у тварин перед щепленням.

Таблиия 1

Гематологічні показники крові щурів за дії препарату «Лейкозав» $(\mathrm{M} \pm \mathrm{m} ; n=5-6)$

\begin{tabular}{|c|c|c|c|c|}
\hline \multirow{2}{*}{ Показники } & \multicolumn{4}{|c|}{ Період досліджень } \\
\cline { 2 - 5 } & $\begin{array}{c}\text { перед } \\
\text { щепленням (контроль) }\end{array}$ & $\begin{array}{c}7 \text { доба після вакцина- } \\
\text { ції }\end{array}$ & $\begin{array}{c}14-\text { та доба після вак- } \\
\text { цинації }\end{array}$ & $\begin{array}{c}30 \text {-та доба після } \\
\text { вакцинації }\end{array}$ \\
\hline $\mathrm{WBC}, 10^{9} / 1$ & $8,63 \pm 0,60$ & $10,33 \pm 1,11$ & $7,85 \pm 0,93$ & $6,95 \pm 0,75$ \\
\hline $\mathrm{RBC}, 10^{12} / 1$ & $6,83 \pm 0,22$ & $6,44 \pm 0,37$ & $6,11 \pm 0,61$ & $6,31 \pm 0,66$ \\
\hline $\mathrm{HGB}, \mathrm{g} / 1$ & $120,5 \pm 2,33$ & $114,17 \pm 4,54$ & $107,33 \pm 10,84$ & $113,20 \pm 10,01$ \\
\hline $\mathrm{HCT}, 1 / 1$ & $0,359 \pm 0,009$ & $0,342 \pm 0,014$ & $0,314 \pm 0,030$ & $0,335 \pm 0,032$ \\
\hline $\mathrm{MCV}, \mathrm{fl}$ & $52,72 \pm 0,74$ & $53,55 \pm 1,65$ & $51,50 \pm 0,98$ & $53,36 \pm 1,00$ \\
\hline $\mathrm{MCH}, \mathrm{pg}$ & $17,72 \pm 0,46$ & $17,88 \pm 0,61$ & $17,57 \pm 0,48$ & $18,10 \pm 0,44$ \\
\hline $\mathrm{MCHC}, \mathrm{g} / 1$ & $334,6 \pm 6,13$ & $333,5 \pm 2,06$ & $341,5 \pm 7,55$ & $339,0 \pm 3,55$ \\
\hline $\mathrm{RDW}, \%$ & $14,50 \pm 0,48$ & $15,07 \pm 0,29$ & $13,55 \pm 0,25$ & $14,64 \pm 0,54$ \\
\hline $\mathrm{PLT}, 10 \% / 1$ & $317,25 \pm 41,42$ & $297,00 \pm 45,30$ & $326,40 \pm 44,89$ & $334,00 \pm 62,75$ \\
\hline $\mathrm{MPV}, \mathrm{fl}$ & $7,12 \pm 0,70$ & $6,28 \pm 0,25$ & $6,87 \pm 0,27$ & $7,28 \pm 0,97$ \\
\hline $\mathrm{PCT}, \mathrm{cl} / 1$ & $0,286 \pm 0,057$ & $0,366 \pm 0,053$ & $0,208 \pm 0,054$ & $0,361 \pm 0,063$ \\
\hline PDW, $\%$ & $17,68 \pm 1,81$ & $16,57 \pm 1,00$ & $19,43 \pm 1,12$ & $15,7 \pm 1,57$ \\
\hline
\end{tabular}

Примітка. У цій та наступній таблицях * $-\mathrm{p}<0,05 ; * *-\mathrm{p}<0,01 ; * * *-\mathrm{p}<0,001-$ вірогідність у тварин дослідної групи, порівняно до контрольної. $\mathrm{N}=5$ - кількість тварин у контрольній групі; n = 6- кількість тварин у дослідній групі

Однак ці показники були невірогідні (збільшення лейкоцитів в крові щурів на сьому добу після щеплення, можна пояснити тим, що введений антиген у вигляді у вигляді лейкозного імунного препарату $є$ концентрованими гетерогенними білками, які спричиняють формування специфічного протилейкозного імунітету.
Зміни показника відносної ширини розподілу еритроцитів характеризують гетерогенність доменних елементів і характеризує, як коефіцієнт варіації їх серед цього об'єму. На 14 добу після щеплення препаратом величина даного показника була вірогідно менша, ніж у щурів на сьому добу після імунізації.

Введення препарату «Лейкозав» щурам не спричиняло вірогідних змін щодо показників тромбоцита- 
рних індексів у крові тварин на сьому добу після щеплення. Представлена лейкограма (табл. 2) свідчить про зменшення кількості сегментоядерних нейтрофілілів і зростання кількості лімфоцитів в одиниці об’єму крові (1 мкл) на 14 та 30 добу після щеплення $(\mathrm{p}<0,05-0,01)$. Такі зміни можуть вказувати на те, що введення проти лейкозного антигену, як специфічного білку, до якого тварини не були генетично пристосовані у процесі еволюції спонукали зниження клітинних факторів захисту і підвищення гуморальних факторів супротиву імунної системи. Збільшення кількості моноцитів в 1,6 рази через 30 діб після іму- нізації $(\mathrm{p}<0,05)$ у порівнянні $з$ довакцинальним періодом свідчать про активізацію фагоцитарної активності клітинного імунітету. Моноцити є попередниками плазматичних клітин, які формуються, як наслідок 3'єднання 3 антигеном. Таке з'єднання забезпечує унікальність макрофагів в інактивації чужорідного антигену, що попав в русло крові. Макрофаги, як основа фагоцитарної системи організму об'єднують функції найбільш активного фагоцитозу, потужного цитотоксичного агента і досить активної антигенпрезентуючої клітини. Моноцити забезпечують функціональну активність макрофагів в плазмі крові.

Таблиия 2

Лейкограма крові щурів за дії препарату «Лейкозав», \% (M \pm m; $n=5$ - 6)

\begin{tabular}{|c|c|c|c|c|}
\hline \multirow[b]{2}{*}{ Показники } & \multicolumn{4}{|c|}{ Період досліджень } \\
\hline & $\begin{array}{c}\text { перед } \\
\text { щепленням } \\
\text { (контроль) }\end{array}$ & $\begin{array}{c}7 \text { доба } \\
\text { після вакцинації }\end{array}$ & $\begin{array}{c}\text { 14-та доба після } \\
\text { вакцинації }\end{array}$ & $\begin{array}{c}\text { 30-та доба після } \\
\text { вакцинації }\end{array}$ \\
\hline Базофіли & $0,25 \pm$ & $0,50 \pm$ & $0,50 \pm$ & $0,75 \pm$ \\
\hline Еозинофіли & $2,25 \pm 0,75$ & $1,25 \pm 0,25$ & $2,00 \pm 0,71$ & $1,75 \pm 0,48$ \\
\hline Юні & 0 & 0 & 0 & 0 \\
\hline Паличкоядерні & $1,25 \pm 0,25$ & $1,75 \pm 0,48$ & $2,25 \pm 0,48$ & $1,25 \pm 0,25$ \\
\hline Сегментоядерні & $35,75 \pm 1,49$ & $36,25 \pm 2,21$ & $28,75 \pm 2,02^{* \circ}$ & $25,75 \pm 1,25 * *$ \\
\hline Лімфоцити & $55,50 \pm 1,55$ & $56,25 \pm 1,65$ & $61,75 \pm 2,72$ & $62,75 \pm 1,89^{*}$ \\
\hline Моноцити & $5,00 \pm 0,82$ & $4,00 \pm 0,91$ & $4,75 \pm 0,85$ & $8,00 \pm 0,71^{*}$ \\
\hline
\end{tabular}

$\mathrm{N}=5$ - кількість тварин у контрольній групі; $\mathrm{n}=6-$ кількість тварин у дослідній групі

3 даних табл. 2 видно, що під впливом препарату «Лейкозав» через два тижні після імунізації в крові тварин збільшується кількість базофілів (в 2 2,5 рази). У порівнянні з контрольною групою тварин еозинофіли крові піддослідної групи щурів знаходяться у межах показників фізіологічної норми.

\section{Висновки}

1. В організмі щурів після вакцинації спостерігається тенденція до зменшення у крові кількості еритроцитів, вмісту гемоглобіну та величини гематокриту, що може вказувати про інгібуючий вплив імунізації на еритроцитопоез і еритроцити.

2. При дослідженні кількості лейкоцитів і співвідношення їх окремих форм у крові щурів на 14- і 30ту добу після щеплення встановлено зменшення кількості сегментоядерних нейтрофілів і збільшення числа лімфоцитів $(\mathrm{p} \leq 0,05-0,01)$ і моноцитів $(\mathrm{p} \leq 0,05)$ на 30-ту добу після імунізації. При цьому різниці у кількості лейкоцитів у крові були невірогідні. Такі зміни можуть свідчити про зниження активності клітинних і підвищення гуморальних факторів захисту під впливом препарату.

3. Введення препарату «Лейкозав» щурам не спричиняє негативного впливу на гематологічні показники піддослідних тварин і їх здоров’я.

Перспективи подальших досліджень. Проведення досліджень імунобіологічних і біохімічних показників крові лабораторних щурів за дії препарату «Лейкозав» проти лейкозу ВРХ.

\section{Бібліографічні посилання}

Sjurin, V.N., Samujlenko, A.Ja., Solov'jov, B.V., Fomina N.V. (2001). Virusnye bolezni zhivotnyh. Moskva: VNITIBP (in Russian).

Gorbatenko, S.K., Shapovalova, O.V., Kornjejkov, O.M., Zdanjevych, P.P. (2014). Naprjamky zapobigannja recydyvu epizootii' lejkozu velykoi' rogatoi' hudoby, Veterynarna medycyna. 98, 84-87 (in Ukrainian).

Gorbatenko, S.K. Shapovalova, O.V. (2013). Do vykorinennja lejkozu velykoi' rogatoi' hudoby $\mathrm{v}$ tvarynnyctvi Ukrai'ny. Veterynarna medycyna Ukrai'ny. 212, 17-19 (in Ukrainian).

Busol, V. (2003). Problema likvidacii' lejkozu. Rannij vyjav ta znyshhennja dzherela infekcii' chy zastosuvannja vakcyny? Zdorov'ja tvaryn ta liky. 7, 6-7 (in Ukrainian).

Gorzhejev, V.M. (2013). Suchasnyj epizootychnyj stan jak zakljuchnyj etap gradacii' lejkozu velykoi' rogatoi' hudoby v Ukrai'ni. Veterynarna medycyna. 97, 164166 (in Ukrainian).

Epizootychna sytuacija v Ukrai'ni stanom na zhovten' 2015 roku [Elektronnyj resurs] http://www.vetgov.ua/node/4321. (in Ukrainian).

Krushel'nyc'kyj, Z., Markiv V. (2004). Ozdorovlennja gospodarstva vid lejkozu velykoi' rogatoi' hudoby iz zastosuvannjam vakcyny. Veterynarna medycyna Ukrai'ny. 5, 27-28 (in Ukrainian).

Nagajeva, L.I., Aranchij, S.V. (2003). Diagnostyka ta profilaktyka lejkozu velykoi' rogatoi' hudoby, Biblioteka veter. Med. Kyi'v. 3. (in Ukrainian).

Zavirjuha, A.I., Zavirjuha, G.A., Gopka, T.B. i insh. (2003). Rezul'taty vykorystannja vakcyny «Lejkozav» u profilaktyci i borot'bi z lejkozom velykoi' rogatoi' 
hudoby, Veterynarna medycyna. Mizhvid. temat. nauk. Zb. Harkiv. 82, 240-246 (in Ukrainian).

Tons'ka, T.G. (2013). Doslidzhennja profilaktychnyh protylejkoznyh preparativ na vivcjah, Naukovi praci PF NUBiP Ukrai'ny «KATU». 155, 281-286 (in Ukrainian).
Zavirjuha, A.A. (2014). Rezul'taty issledovanij krovi molodnjaka krupnogo rogatogo skota do i posle immunizacii vakcinoj «Lejkozav». Jepizootologija Immunologija Farmakologija Sanitarija. Mezhdunarod. Nauchn. 2, 24-28 (in Ukrainian).

Стаття надійила до редакиії 5.10.2016 